\title{
Relationship between carotid atheroma thickness and albuminuria in diabetic patients
}

\author{
Dr. Basim Audib Motar *, Dr. Methaq A. M. Hussein *, \\ Dr. Oras Majeed** \\ *Assistant professor, department of medicine, college of medicine / Thi-Qar University. \\ ***Radiologist, Thi-Qar health Office
}

\begin{abstract}
Our aim in this study to assess the efficacy of albuminuria in type 2 diabetes mellitus to be as predictor and independent marker of atherosclerosis by measurement of carotid intimal-medial thickness (CIMT) by high frequency ultrasonography.
\end{abstract}

One hundred twenty participants in this study, 45 as a control healthy person and the others 75 patients with type 2 diabetes mellitus were included in this study. We divided into three groups: group 1 which is the control group, and group 2 those patients who are the diabetic without albuminuria, and group 3 are the diabetic patients with albuminuria.

The intimal-medial thickness (IMT) was measured by high frequency ultrasonography.
Other laboratory investigations were measured like $\mathrm{HbA1c}$, fasting blood sugar, lipid profile. The intimal-medial thickness (IMT) was found higher in group 3 than group 1 and group $2(\mathrm{P}$ value $<0.05)$. In conclusion, there is a significant association between micro- albuminuria and IMT as a marker of atherosclerosis in type 2 diabetes mellitus.

\section{INTRODUCTION}

Diabetes is a group of metabolic

disorders characterized by a chronic hyperglycemic condition resulting from insufficient action of insulin. Type 2 diabetes mellitus is caused by a combination of genetic factors related to impaired insulin secretion and insulin resistance and environmental factors such as obesity, overeating, lack of exercise, and stress, as well as aging. It is typically a 


\section{utjmed@utq.edu.iq}

multifactorial disease involving multiple genes and environmental factors to varying extents. Compared with people without diabetes, affected individuals are at increased risk for both cardiovascular events and kidney disease $(1,2)$. In addition, diabetes mellitus is the most common cause of renal damage and end - stage renal disease, moreover, the earliest sign of diabetic nephropathy is microalbuminuria which can lead to macroalbuminuria and progressive kidney function impairment ${ }^{(3)}$. Increased urinary protein excretion may be an early clinical manifestation of diabetic nephropathy (4-8). However, when assessing protein excretion, the urine dipstick is a relatively insensitive marker for initial increases in protein excretion, not becoming positive until protein excretion exceeds 300 to $500 \mathrm{mg} /$ day (upper limit of normal less than $150 \mathrm{mg} / \mathrm{day}$, with most individuals excreting less than 100

$$
\mathrm{mg} / \text { day) }{ }^{(8)} \text {. }
$$

Using a specific assay for albumin is a

more sensitive technique. The normal rate of albumin excretion is less than $30 \mathrm{mg} / \mathrm{day}(20 \mu \mathrm{g}$ / minute); persistent albumin excretion between 30 and $300 \mathrm{mg} /$ day (20 to $200 \mu \mathrm{g} / \mathrm{min}$ ) is called microalbuminuria ${ }^{(9)}$. bassim-a@utq.edu.iq

methaq-abd@utq.edu.iq

Protein excretion above $300 \mathrm{mg} /$ day

(200 $\mu \mathrm{g} / \mathrm{min}$ ) is considered to represent macroalbuminuria (also called overt proteinuria, clinical renal disease, or dipstick positive The reported prevalence of proteinuria) ${ }^{(9)}$. microalbuminuria among patients with type 2 diabetes mellitus approximately 10 years after the diagnosis ranges from $25-40 \%(10-14)$. Increased urinary albumin excretion (albuminuria) and reduced glomerular filtration rate (GFR) are risk factors for progressive kidney failure and cardiovascular disease ${ }^{(15)}$. Several biochemical parameters including soluble vascular cell adhesion molecule 1, sialic acid, C-reactive protein, and fibrinogen have been proved to be significantly associated with microalbuminuria (15-18) and those paremeters were believed to indicate endothelial dysfunction and chronic inflammation, and these findings may support a hypothesis that microalbuminuria reflects generalized vascular damage which may promote atherosclerosis (19,20), moreover, microalbuminuria is the most reliable marker of diabetic nephropathy and an index of atherosclerosis and cardiovascular mortality in type 2 diabetic patients ${ }^{(21,23)}$. 
Atherosclerosis is the main cause of

cardiovascular disease; measurement of intimalmedial thickness (IMT) enables the detection of atherosclerotic lesions of the arterial wall ${ }^{(24)}$, on the other hand, the carotid intima-media thickness (CIMT) is a sensitive marker of early carotid atherosclerosis; thus, measurement of the CIMT by ultrasonography can be used to assess the cardiovascular risk and to determine indications for better management of diabetes and intensified treatment ${ }^{(23)}$.

The CIMT can be measured by high frequency B mode ultrasonography, which provides a high degree of accuracy in estimating the arterial wall thickness ${ }^{(25)}$. The CIMT is significantly higher in diabetic patients than in non-diabetic patients ${ }^{(25)}$, and the increased IMT can predict future events of silent brain infarction and coronary heart disease in the patients with type 2 diabetes mellitus ${ }^{(26,27)}$. Inaddition, the increases in the CIMT may be associated with an increased risk of myocardial infarction and stroke in aged patients without a history of cardiovascular disease $^{(21)}$. Subjects, Materials and methods
Barticipants: The study included 120 persons, 45 healthy persons (control group, group 1), age range $40-62$ years, 23 were males and 22 were females. The other 75 persons were type 2 diabetic patients and divided into 2 groups:

Group 2 involved 46 patients with normoalbuminuria, 26 males and 20 patients were females.

Group 3 involved 29 patients with microalbuminuria (urinary albumin excretion rate $\{\mathrm{UAER}\}$ is $30-300 \mathrm{mg} / 24$ hours' urine collection) and include 14 males and 15 females.

The age in both groups 2 and 3 was range from $42-74$ years and the duration of type 2 diabetes mellitus was $4-11$ years and all patients on diet and oral hypoglycemic drugs. Medical history was obtained and physical examination was performed in all patients. Blood samples were withdrawn from all subjects following 12 hour of fasting. We measured body mass index (BMI), Blood pressure both systolic and diastolic blood pressure, fasting blood sugar (FBS) and glycated hemoglobin (HbA1c), lipid profile, UAER, IMT by carotid artery ultrasonography. 
Serum concentrations of total cholesterol (TC), triglyceride (TG), low density lipoprotein (LDL), high density lipoprotein (HDL), and FBS were measured by enzymatic method. HbA1c was measured by high performance liquid chromatography. UAER was obtained by a 24-hour urine collection. Body mass index (BMI) was calculated as weight in kilograms divided by height in meter squared.

\section{Exclusive criteria:}

Renal impairment, type 1 diabetes

mellitus, hypertension, ischemic heart disease, valvular heart disease was excluded from the study.

The conditions that could cause transient elevations in urinary albumin excretion, such as exercise, urinary tract infection, febrile illness, were also excluded from the study.

\section{Carotid artery ultrasonography:}

An experienced specialist performed

carotid artery ultrasonography. A real-time ultrasound scan was used: Hitachi EUB 7500 with an electrical linear transducer (mid frequency of 7.5 MHz probe, Hitachi Medical System, Japan). All subjects were examined in the supine position with the head turned $45^{\circ}$ contralateral to the side of scanning. The scanning session lasted for an average of 30 minutes. B-mode images were obtained in longitudinal section. IMT was defined as the distance between the lumen-intima and the media-adventitia ultrasound interfaces. The IMT on the far wall of the bilateral common carotid artery about $10 \mathrm{~mm}$ proximal to the bifurcation of the carotid artery was measured Three measurements on both sides .manually ${ }^{(28,29)}$ were performed for each subjects and the mean value was obtained for analysis. Carotid IMT values below $0.8 \mathrm{~mm}$ were considered as normal ${ }^{(29)}$.

The presence of plaques and degree of stenosis was noted and analyzed. Plaque was defined as a localized lesion of thickness $\geq 1 \mathrm{~mm}$; $50 \%$ occlusion with $>$ stenosis was defined as systolic frequency peak $\geq 4 \mathrm{KHz}$ and spectral broadening ${ }^{(30)}$.

Statistical analysis: The software of SPSS

version 13 for Windows (SPSS Inc., IL USA) was used for statistical analysis. Statistical significance between two groups was determined by Wilcoxon rank-sum test. Continuous variables were expressed as median and range. Pearson's chi-square test was used to compare groups regarding categorical variables. Correlation analysis including Pearson's for continuous and Spearman's for discrete variables 


\section{utjmed@utq.edu.iq}

and multiple linear stepwise regression analysis was used to show the influences of variables on IMT. Multivariate regression analysis was computed with $<$ the SPSS statistical software package and $\mathrm{P}$ values 0.05 were considered significant.

RESULT

A total of one hundred and twenty (120)

participants were included in the study; 45 healthy persons as control group (group 1) which are non diabetic, and 75 patients with type 2 diabetes bassim-a@utq.edu.iq

methaq-abd@utq.edu.iq

mellitus with or with out albuminuria (group 2 and

group 3).

Table 1 shows the characteristics of this

study which revealed that Group 3 showed elevated UAER and also more BMI with poor $\mathrm{HbA1c}$, and this group showed more IMT than those with group 2 as evident in figure 1.

Table 1: characteristics of the study

\begin{tabular}{|c|c|c|c|c|}
\hline Characteristics & $\begin{array}{c}\text { Group 1 } \\
\text { No. = 45 }\end{array}$ & $\begin{array}{c}\text { Group 2 } \\
\text { No.= 46 }\end{array}$ & $\begin{array}{c}\text { Group 3 } \\
\text { No.= 29 }\end{array}$ & P value \\
\hline Sex ( M / F ) & $23 / 20$ & $26 / 20$ & $14 / 15$ & NS \\
\hline Age ( years ) & 50.1 & 47.7 & 53.6 & NS \\
\hline Smokers ( \% ) & $37 \%$ & $29 \%$ & $33 \%$ & NS \\
\hline Duration of DM & NO & 5.9 & 7.3 & NS \\
\hline BMI ( Kg/M ${ }^{2}$ ) & 24.1 & 25.1 & 26.2 & NS \\
\hline Systolic BP & 118.2 & 120.1 & 119.1 & NS \\
\hline DBG ( mmol ) & 5.5 & 8.9 & 75.2 & $<.05$ \\
\hline
\end{tabular}


Thi-Qar Medical Journal (TQMJ): Vol.(11), No.(1), 2016

utjmed@utq.edu.iq

bassim-a@utq.edu.iq

methaq-abd@utq.edu.iq

\begin{tabular}{|c|c|c|c|c|}
\hline HbA1c (\%) & 5.8 & 7.1 & 8.2 & $<0.05$ \\
\hline IMT ( mm ) & 0.49 & 0.72 & 0.94 & $<0.05$ \\
\hline UAER( mg / 24 hr ) & 10.9 & 11.1 & 70.2 & $<0.05$ \\
\hline TG (mmol/L) & 1.4 & 1.56 & 2.4 & $<0.05$ \\
\hline LDL (mmol/L) & 3.2 & 3.33 & 4.1 & $<0.05$ \\
\hline
\end{tabular}

\begin{tabular}{|l|l|l|l|l|}
\hline HDL (mmol/L) & 0.89 & 0.91 & 0.92 & NS \\
\hline
\end{tabular}

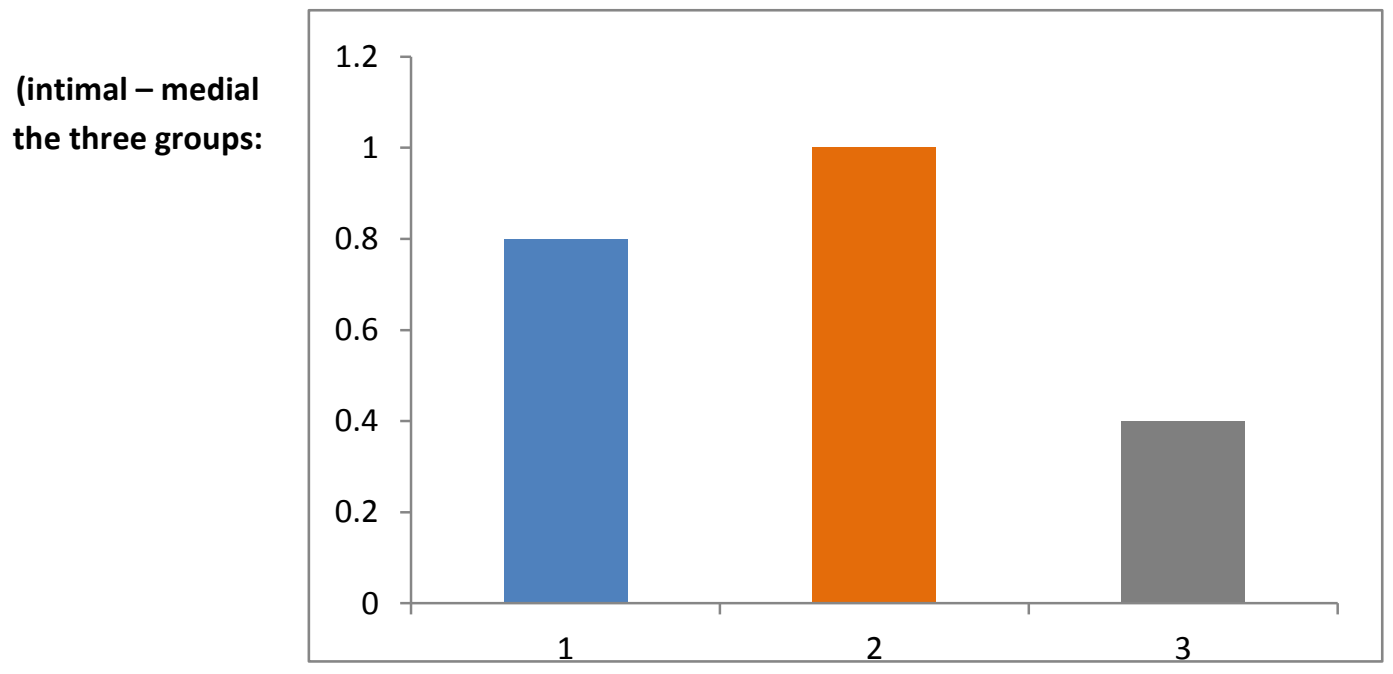

Figure 1: Shows IMT

thickness) between

1- DM type 2 with no albuminuria ( group 
Thi-Qar Medical Journal (TQMJ): Vol.(11), No.(1), 2016

utjmed@utq.edu.iq

bassim-a@utq.edu.iq

methaq-abd@utq.edu.iq

2- DM type 2 with albuminuria (group

3- Control group $\quad$ (group 1

Figure 2: shows the differences regarding UAER between the three groups.

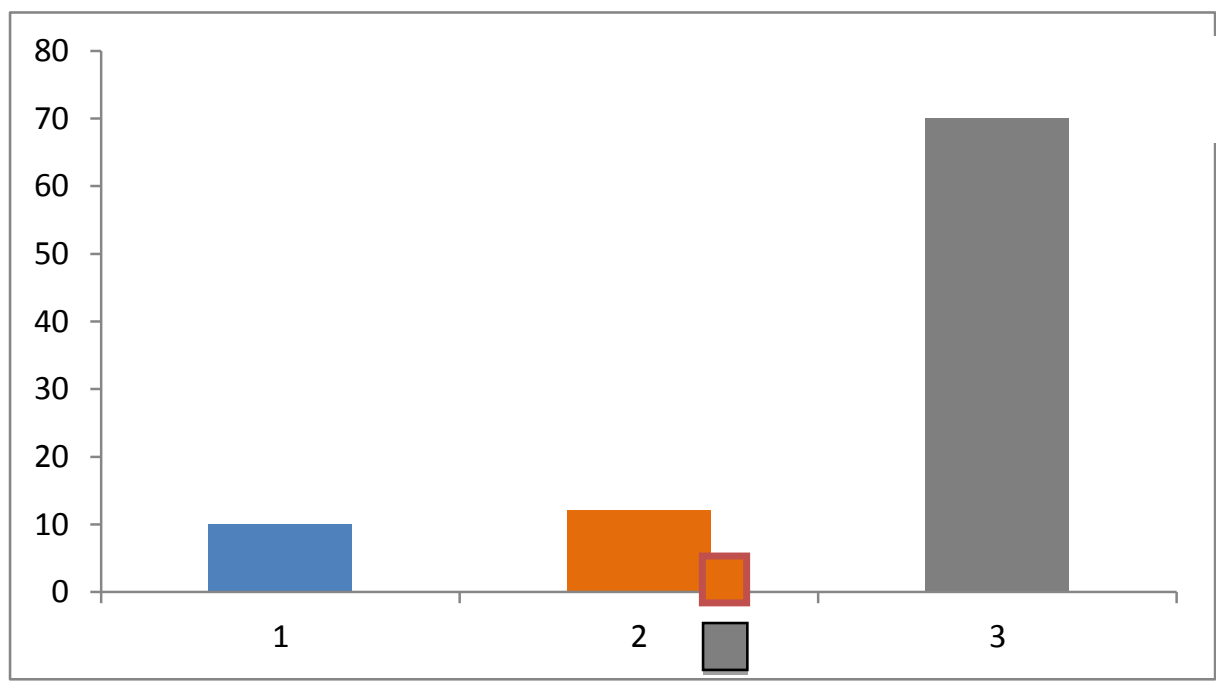

$\operatorname{IMT}(\mathrm{mm})$

(group 1)

(group 2)

(group 3)

Figure : 4 shows percent of patient with pooly control DM in groub 2

(with out albuminuria

\section{UAER $(\mathrm{mg} / 24$}

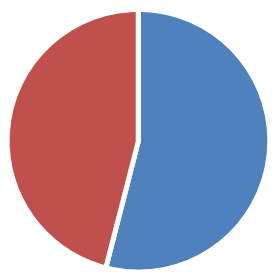

- poorly control a good control figure 3 : shows the percent of patient in group 3 whose poorly control DM

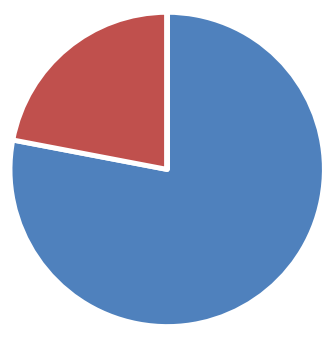

- poorly control good controll 


\section{DISCUSSION}

In our study, we found that IMT (as a

marker of atherosclerosis) was higher in type 2 diabetic patients with albuminuria than those with normal urinary albumin excretion, so the presence of albuminuria in type 2 diabetic patients considered as independent risk factor and predictor of IMT and atherosclerosis.

It is known that there is a relationship

between diabetic nephropathy and atherosclerosis in many studies, N. Nand, et al. (31) results showed that albuminuria was associated with carotid atherosclerosis in middle age individuals. But this study not limited to diabetic patients.

D. A. Stehouwer, et al. (32) showed that albuminuria was associated with impaired endothelium - dependent, flow-mediated vasodilatation in old age group with and without diabetes. Yu-Hong Zhang, et al. ${ }^{(33)}$ showed that there was significant association between microalbuminuria and IMT in diabetic patients only.

Dick de Zeeuw study showed that albuminuria is a clear marker of cardiovascular morbidity and mortality ${ }^{(34)}$. In the same time, this study showed that the value of HbA1c in type 2 diabetic patients with microalbuminuria was significantly higher than that in patients with normoalbuminuria. IMT was significantly associated with HbAlc. The result indicated that $\mathrm{HbA1c}$ may be played an important role in the relationship between carotid atherosclerosis and microalbuminuria. HbA1c can accurately reflect long term glycemic control. HbA1c is now used to assess glycemic control in diabetic patients, and also consider an important test for screening and diagnosis of the diabetes.

$\mathrm{HbA1c}$ is considering a very beneficial marker for diabetic microvascular complications ${ }^{(35)}$. 
Also, HbA1c is associated with advanced

$$
\text { glycation end products (AGEs) }{ }^{(36)} \text {. }
$$

Our study has its limitations; including

the study population is small, and some

patients with type 2 diabetes mellitus have

been already treated with antihyperlipidemic

agents which may lead to inaccuracy of the

results.

\section{CONCLUSIO}

Our study shows that there is significant

association between microalbuminuria and
IMT which consider as the early sign of carotid atherosclerosis in patients with type 2 diabetes mellitus. Detection of carotid artery IMT and plaque in type 2 diabetic patients with microalbuminuria is very important for detecting early atherosclerosis and prevent toward the development of diabetic nephropathy and cardiovascular insults. Larger and further studies are needed to confirm our results. 


\section{REFERENCES}

1- Unoki H, Takahashi A, Kawaguchi T, et al. SNPs in KCNQ1 is associated with susceptibility to type 2 diabetes in East Asian and European populations. Nat Genet. 2008; 40: 1098-1102.

2- Abdul-Ghani MA, Matsuda M, Jani R, et al. The relationship between fasting hyperglycemia and insulin secretion in subjects with normal or impaired glucose tolerance. Am J Physiol Endocrinol Metab. 2008; 295: E401-E406.

3- Momeni A, Beharadmanesh MS, Kheiri S, Horestani MK. Evolution of spironolactone plus hydrochlorothiazide in reducing proteinuria in type 2 diabetic nephropathy. $\mathbf{J}$ Renin Angiotensin Aldosterone Syst. 2013.

4- K/DOQ1 clinical practice guidelines and clinical practice recommendations for diabetes and chronic kidney disease. Am J Kidney dissing 2007; 49(2 Suppl 2): S12.

5- Gross JL, de Azevedo MJ, Silveiro SP, et al. Diabetic nephropathy: diagnosis, prevention, and treatment. Diabetes Care 2005; 28:164.

6- Ruggenenti P, Remuzzi G. Nephropathy of type 2 diabetes mellitus. J Am Soc Nephrol 1998; 9:2157.

7- Ismail N, Becker B, Strzelczyk P, Ritz E. Renal disease and hypertension in non-insulindependent diabetes mellitus. Kidney Int 1999; 55:1. 
8- Mogensen CE, Vestbo E, Poulsen PL, et al. Microalbuminuria and potential confounders. A review and some observations on variability of urinary albumin exretion. Diabetes Care 1995; 18:572.

9- Eknoyan G, Hostetter T, Bakris GL, et al. Proteinuria and other markers of chronic Kidney disease: a position statement of the national Kidney foundation (NKF) and the national institute of diabetes and digestive and kidney diseases (NIDDK). Am J Kidney Dis 2003; 42:617.

10- Newman DJ, Mattock MB, Dawnay AB, et al. Systemic review on urine albumin testing for early detection of diabetic complications. Health Technol Assess 2005; 9: III.

11- Advance Collaborative Group, Patel A, MacMahon S, et al. Intensive blood glucose control and vascular outcomes in patients with type 2 diabetes. N Engl J Med 2008; 358:2560.

12- Adler Al, Stevens RJ, Manley SE, et al. Development and progression of nephropathy in type 2 diabetes: The United Kingdom Prospective Diabetes study (UKPDS 64). Kidney Int 2003; 63:225.

13- Young BA, Katon WJ, Von Korff M, et al. Racial and ethnic differences in microalbuminuria prevalence in a diabetes population: the pathways study. J Am Soc Nephrol 2005; 16:219.

14- Parving HH, Lewis JB, Ravid M, et al. Prevalence and risk factors for microalbuminuria in a referred cohort of type 2 diabetic patients: a global perspective. Kidney Int 2006; 69:2057.

15- Perkovic V, Verdon C, Ninomiya T, Barzi F, Cass A, Patel A, et al. The relationship between proteinuria and coronary risk: a systematic review and meta-analysis. PLos Med. 2008; 5(10).

16- C. D. A. Stehouwer, M. A. Gall, J.W.R. Twisk, E. Knudsen, J. J. Emeis, and H. H. Parving, " Increased urinary albumin excretion, endothelial dysfunction: progressive, interrelated, and independency associated with risk of death, " Diabetes, vol. 51, no. 4 pp.1157-1165, 2002.

17- H. Yokohama, J. S. Jensen, B. Myrup, E. R. Mathiesen, B. Ronn, and T. Deckert, " Raised serum sialic acid concentration precedes onset of microalbuminuria in IDDM: a 10-year follow up study," Diabetes Care, vol. 19, no. 5, pp. 435 - 44-, 1996.

18- T. Jensen, J. Bjerre-Knudsen, B. Feldt-Rasmussen, and T. Deckert," Features of endothelial dysfunction in early diabetic nephropathy," The Lancet, vol. 1, no. 8636, pp. 461-463, 1989.

19- T. Deckert, B. Feldt-Rasmussen, K. Borch-Johnsen, T. Jensen, and A. Kofoed-Enevoldsen, " Albuminuria reflects widespread vascular damage. The steno hypothesis," Diabetologia, vol. 32, no. 4, pp. 219-226, 1989.

20- T. Deckert, T. Jensen, B. Feldt-Rasmussen, A. Kofoed-Enevoldeen, K. Borch-Johnsen, and S. Stender, " Albuminuria a risk marker of atherosclerosis in insulin dependent diabetes mellitus," Cardiovasc Risk Factors, no. 1, pp. 347-360, 1991.

21- Nichols WW, Pepine CJ, O'Rourke MF. Carotid - artery intima and media thickness as a risk factor for myocardial infarction and stroke. N Engl J Med. 1990; 340:1762-3.

22- Kota SK, Mahapatra GB, Naveed S, Tripathy PR, Jammula S, Modi KD. Carotid intima media thickness in type 2 diabetes mellitus with ischemic stroke. Indian J Endocrinol Metab. $2013 ; 17: 716-22$. 
23- Nathan DM, Lachin J, Cleary P, et al. Intensive diabetes therapy and carotid intima-media thickness in type 1 diabetes mellitus. N Engl J Med. 2003; 348:2294-303.

24- Ito H, Komatsu Y, Mifune M, Antoku S, Ishida H, Takeuchi Y, et al. The estimated GFR, but not the stage of diabetic nephropathy graded by the urinary albumin excretion, is associated with the carotid intima-media thickness in patients with type 2 diabetes mellitus: a crosssectional study. Cardiovasc Diabetol.2010; 9:18.

25- Temelkova-Kurktschiev TS, Koehler C, Leonhardt W, Schaper F, Henkel E, Siegert G, et al. Increased intimal-medial thickness in newly detected type 2 diabetes: risk factors. Diabetes Care. 1999; 22(2):333-8.

26- Bernard S, Serusclat A, Targe F, Charriere S, Roth O, Beaune J, et al. Incremental predictive value of carotid ultrasonography in the assessment of coronary risk in a cohort of asymptomatic type 2 diabetic subjects. Diabetes Care.2005; 28(5):1158-62.

27- Shinoda-Tagawa T, Yamasaki Y, Yoshida S, Kajimoto Y, Tsujino T, Hukui N, et al. A phosphodiesterase inhibitor, cilostazol, prevents the onset of silent brain infarction in Japanese subjects with type 2 diabetes, Diabetologia, 2002;45(2):188-94.

28- P.S. Sidhu and S.R. Desai, " A simple and reproducible method for assessing intimal-medial thickness of the common carotid artery," British Journal of Radiology, vol.70, pp. 85-89, 1997.

29- J. T. Salonen and R. Salonen, "Ultrasonographically assessed carotid morphology and the risk of coronary heart disease," Arteriosclerosis and Thrombosis, vol. 11 no. 5, pp. 1245-1249, 1991.

30- J. T. Johnson, M. M. Kennelly, and D. Decesare, " Natural history of asymptomatic carotid plaque, " Archives of surgery, vol. 120, no. 9, pp. 1010-1012, 1985.

31- N. Nand, R. Jain, S. Seth, J. Sen, and M. Sharma, " a new marker of carotid atherosclerosis in middle aged adults: cystatin cormicroalbuminuria, " Indian Heart Journal, vol. 62, no. 4, pp. 320-323, 2010.

32- C. D. A. Stehouwer, R. M. A. Henry, J. M. Dekker, Nijples, R. J. Heine, and L. M. Bouter, " Microalbuminuria is associated with impaired brachial artery, flow-mediated vasodilatation in elderly individuals without and with diabetes: further evidence for link between microalbuminuria and endothelial dysfunction - the Hoorn Study," Kidney International, vol.66, supplement 92, pp. S42-S44, 2004.

33- Yu-Hong Zhang, Yuan Gao, Xin Mao, Jing Shang, and Ben-Li Su, "Assessment of Carotid Atherosclerosis in Type 2 Diabetes Mellitus Patients with Microalbuminuria by HighFrequency Ultrasonography," International Journal of Endocrinology, vol. 2013, Article ID 819584, 6 pages.

34- Dick de Zeeuw, " Albuminuria, just a Marker for Cardiovascular Disease, Or Is It More?" J Am Soc Nephrol 2005; 16:1883-1885. 
35- M. Furtner, S. Kiechl, A. Mair, et al., " Urinary albumin excretion is independently associated with carotid and femoral artery atherosclerosis in the general population," European Heart Journal, vol.26, no. 3, pp. 279-287, 2005.

36- C. D. Saudek and J. C. Brick, " The clinical use of hemoglobin A1c," Journal of diabetes Science and Technology, vol. 3, no. 4, pp. 629-634, 2009.

$$
\text { العلاقة بين تصلب الشريان السباتي والبول الزلالي عند مرضى داء السكري }
$$

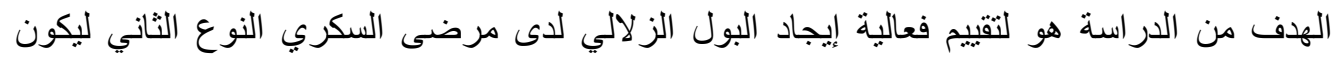

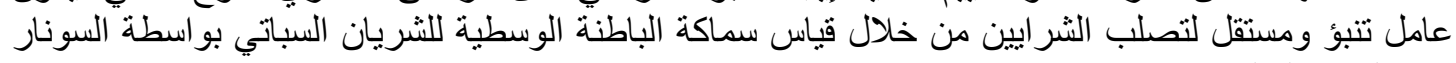
ذات التردد العالي.

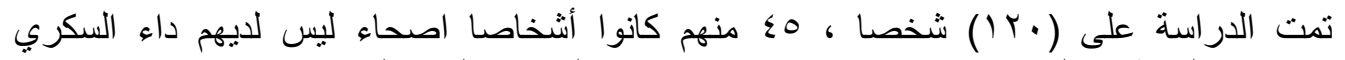

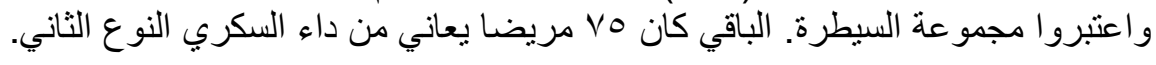

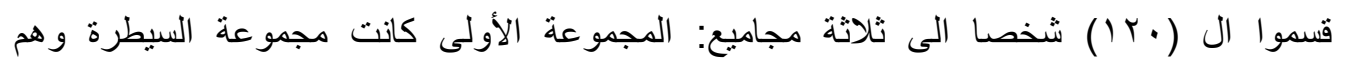

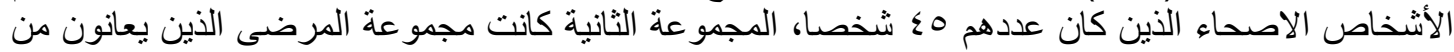

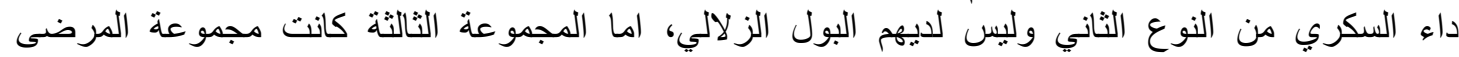

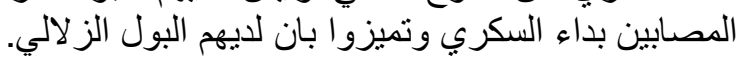

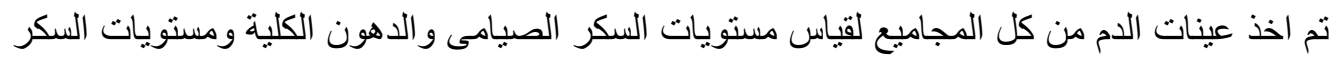
التراكمي. كما تم قياس سماكة الباطنة الوسطية للشريان السباتي بواسطة السونار ذات التردئ الترد العالي لكل مجاميع الدراسة.

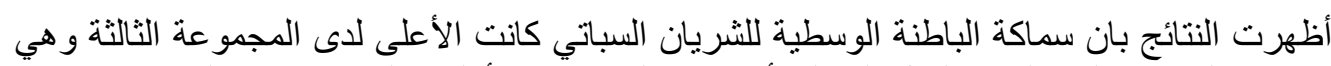

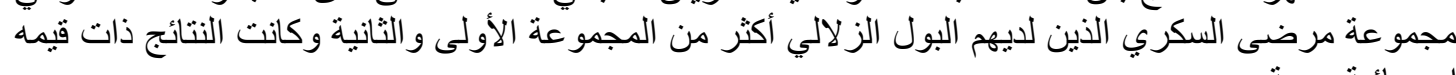

تم الاستنتاج بان هناك علاقة قيمه بين البول الزلالي وسماكة الباطنة الوسطية للشريان السباتي

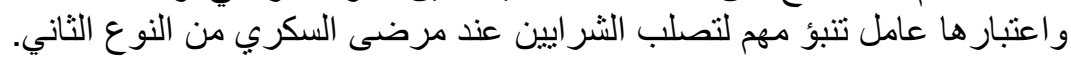

$$
\text { ***أستاذ مساعد - فرع الطب الباطني ـ كلية الطب / جامعة ذي قار }
$$

